
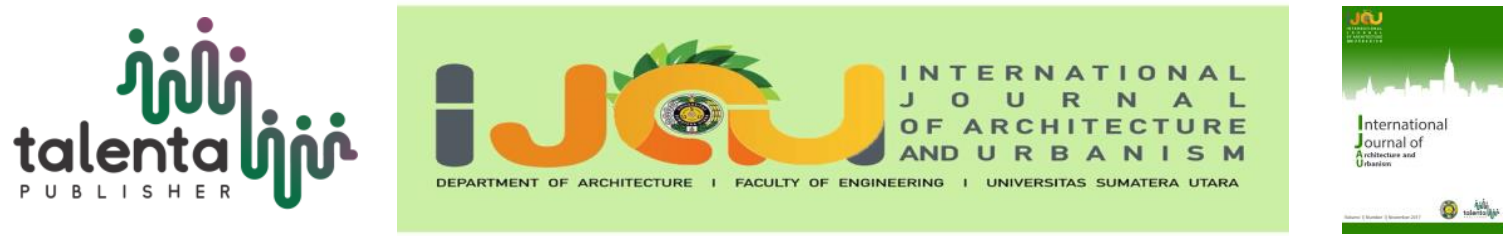

\title{
Designing Majuah-juah Tongging Hotel Resort with Neo- Vernacular Architecture Approach
}

\author{
Ilham Azhar Badrawi ${ }^{1}$ *, Wahyu Utami ${ }^{1}$ \\ ${ }^{1}$ Architectur Departement, Faculty of Engineering, Universitas Sumatera Utara, Medan, Indonesia
}

\begin{abstract}
Tongging Village is a tourist village located on the shores of Lake Toba. The natural wealth is owned by Tongging villages such as Sipiso-Piso waterfall which is the highest waterfall in Indonesia, also Sapo Juma which is a flower garden and camping area not far from the site location. However, with the natural wealth of various tourist areas in Tongging Village has not been developed optimally. Accommodation in the village is also still very restricted because of this the need for supporting facilities that add visitors to the region. The application of Neo-Vernacular architecture aims to revive the traditional Siwaluh Jabu house which many people have forgotten. In this building, the concept of neo-vernacular architecture is seen regarding physical and non-physical aspects. If viewed from a physical point of view, this building uses materials and ornaments in traditional Karo houses and is also seen on the non-physical side of a traditional Karo house use double-loaded corridors and more flexible use of space. A resort Hotel in Tongging village that applies Neo-Vernacular architecture is expected to be an indicator of increased tourism and a reminder of traditional homes in the villages of Tongging and also North Sumatra.
\end{abstract}

Keyword:accommodation, architecture, hotel,neo-vernacular, resort.

\section{Introduction}

According to Law no.10 of 2019 Tourism is a wide range of tourism activities and is supported by various facilities and services provided by the community, entrepreneur, government and local government. Tourism activities can provide wonderful benefits for the development of an area. Tourism also plays a role in helping the economy of most people who depend on the tourism sector.

The increasing number of local and foreign tourists, every year needs to improve the quality of the facilities and infrastructure of each tourist attraction in particular in the regions of North Sumatra. One of the most highlighted attractions in the region of North Sumatra is Lake Toba. Lake Toba has a very beautiful natural wealth so it has the potential to be developed. Tongging Village, Merek District, Karo District, North Sumatra Province is one of the tourist villages that are rarely known by tourists visiting in the Lake Toba area. Even

\footnotetext{
*Corresponding author at: Department of Architecture, Faculty of Engineering, University of North Sumatra, Perpustakaan Street, J07 Building, Medan, 20155, Indonesia.

E-mail address: oscarhalawa@gmail.com
} 
though, Tongging Village has potent natural tourism potential, among others Sipiso-Piso Waterfall which is the highest waterfall in Indonesia with a height of 120 meters. Not only that in Tongging Village there is also Sapo Juma flower garden, located not too far from Siposo-Piso and near Tongging Village is also there is a Paropo campground, its location not too far from Tongging Village. Tongging Village is a tourist area that is rarely developed optimally by the government. Accommodation for tourists to the area is still limited. Therefore for the development of tourism in the zone need to be built some supporting facilities including a hotel resort.

The resort is a planned area that is not just to stay but also for rest and recreation [1]. The design of the resort hotels implements the Neo vernacular architecture. The application of Neo vernacular architecture is expected to protect the identity of the place and can add new knowledge and improve the quality of tourist activities. Neo vernacular architecture is also intended for the use of cultural elements such as material, cultural values, Karo architectural form can be interpreted well and create harmony in the community and nature around the region [2].

\section{Literature Review}

The location is in the village of Tongging, Merek District, Karo District, North Sumatera Province. The location of the site is on the outskirts of Lake Toba (Figure1).

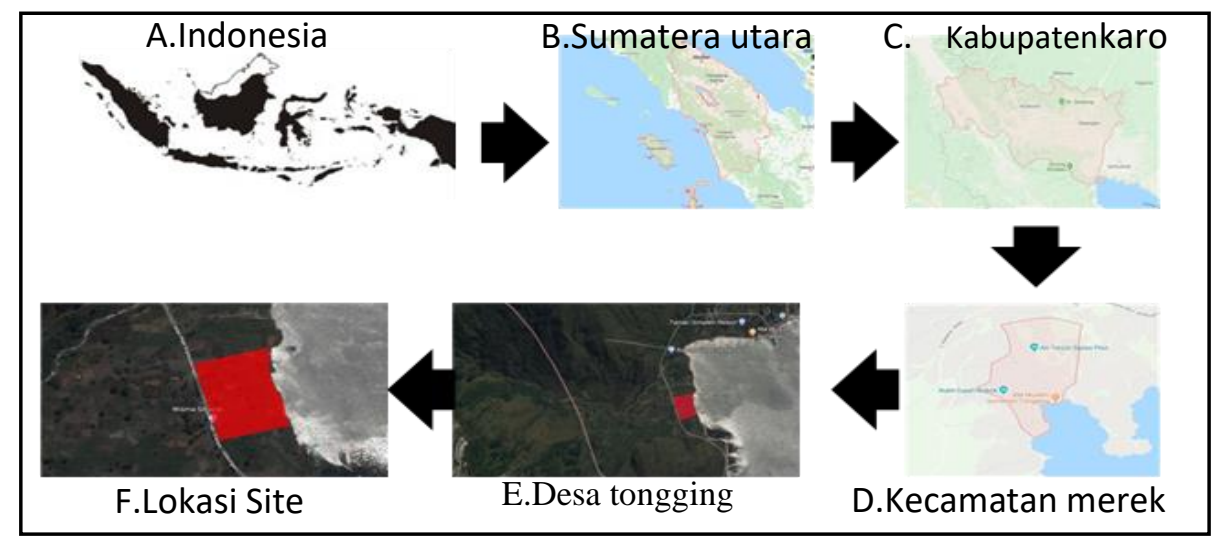

Figure 1. Site Location

The design process this hotel Resort is implemented by the Architecture Neo-Vernacular theme of Karo. The application Architecture Neo-Vernacular of Karo is expected to be able to maintain the local wisdom of Tongging Village which is still closed with the tradition of Karo. Implementation concept of flexibility from Karo traditional house Siwaluh Jabu is one of the implementations of the theme on the intangible element [3]. While the tangible formation of custom Karo house that was adopted by the buffalo head formation became the design benchmark in the theme of the Neo-Vernacular in this resort hotel. 
Le Meridien Hotel Jimbaran Bali is a comparative study of similar buildings. Where the hotel is able to present the application of the Neo-Vernacular Bali. In addition, the experience of space that is presented from the building and also the landscape arrangement to adopt from traditional Balinese architecture. The location of the building is located on the edge of the sea so that the orientation of the Hotel leads to the sea and presents a very beautiful view from that sea that is

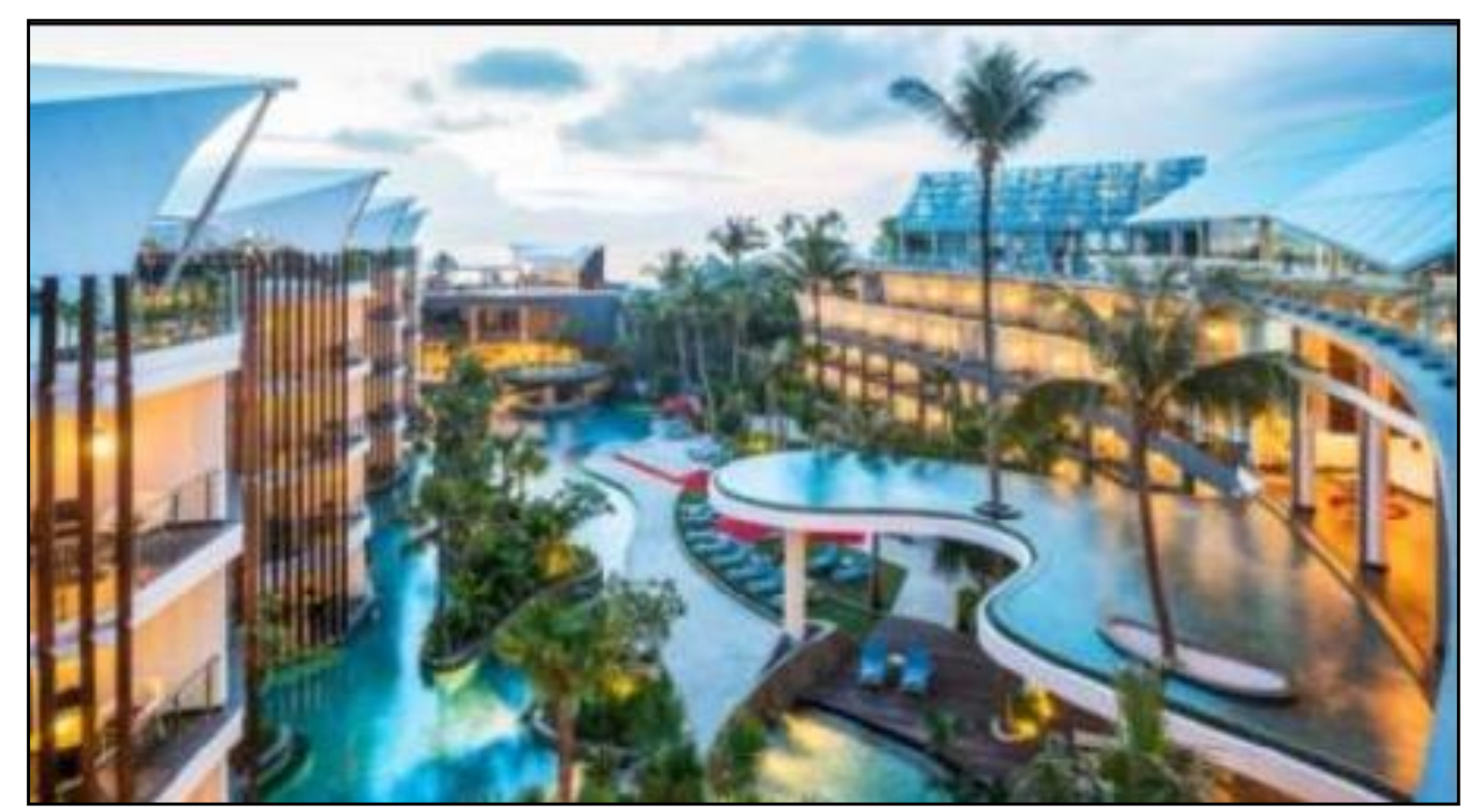

presented in every hotel room available at Le Meridien Hotel Jimbaran Bali (Figure 2).

Figure 2. Hotel Le-meridian Jimbaran Bali

\section{Methodology}

This research uses the ethnography approach. Ethnographic studies describe and interpretation of cultures, social groups or systems. The ethnographic method being used in this study refers to the ethnographic method that has been described by Spradley (2007). Ethnographic cultural studies focus on qualitative research on value and meaning in the context of the whole way oflife, that is, with issues of culture, the world of life and identity. In media-oriented cultural studies, ethnography is a word that represents some qualitative methods, including observation of engagements, in-depth interviews and focuses on group discussions.

\section{Result and Discussion}

The application of flexibility from Traditional Karo houses Siwaluh Jabu is applying in this hotel resort. It is the intangible element that applies from that theme building concept (Figure 3). The flexibility applied to the inside of the hotel and also landscape (Figure 5) and, the formation of Traditional Karo houses that adapts the buffalo head shape into a concept of the main 
building is the representative of Architecture Neo-Vernacular Karo in this hotel resort (Figure 4).

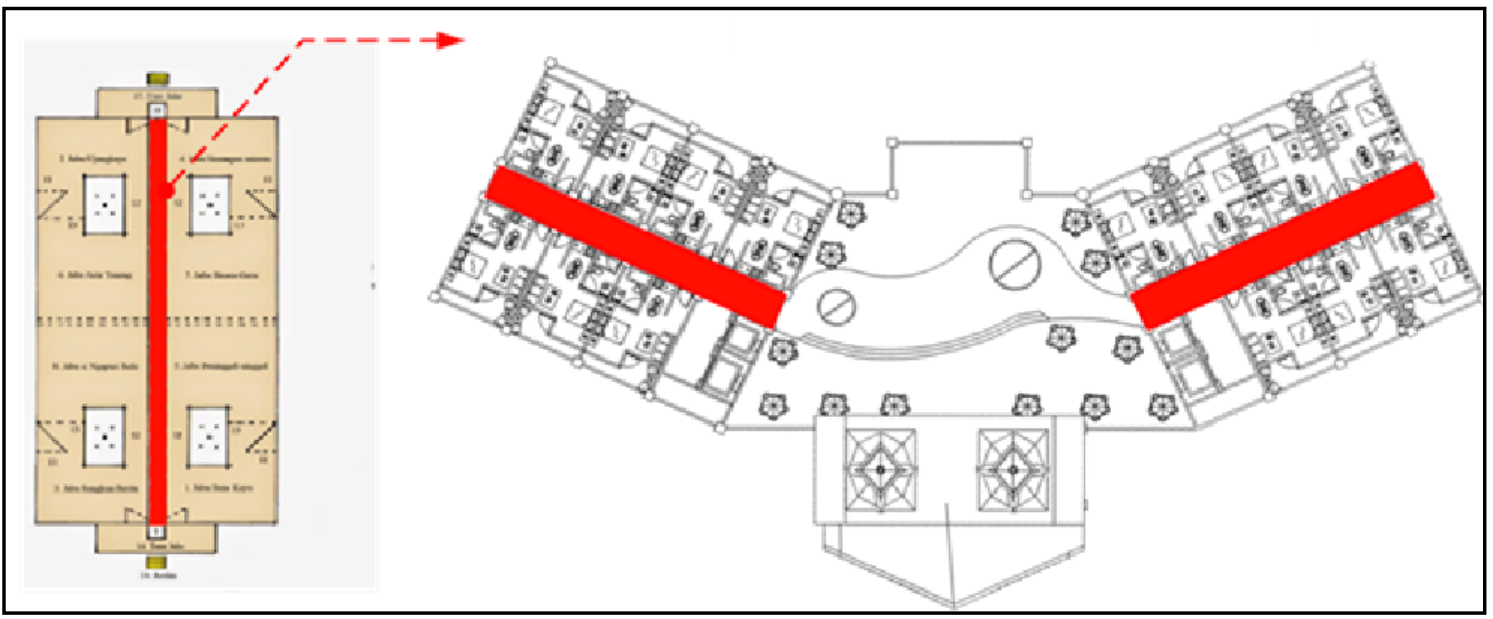

Figure 3.(a)Sirculation of Traditional House of Karo (b)Sirculation of Majuah-Juah Hotel Resort that apply from Traditional House of Karo

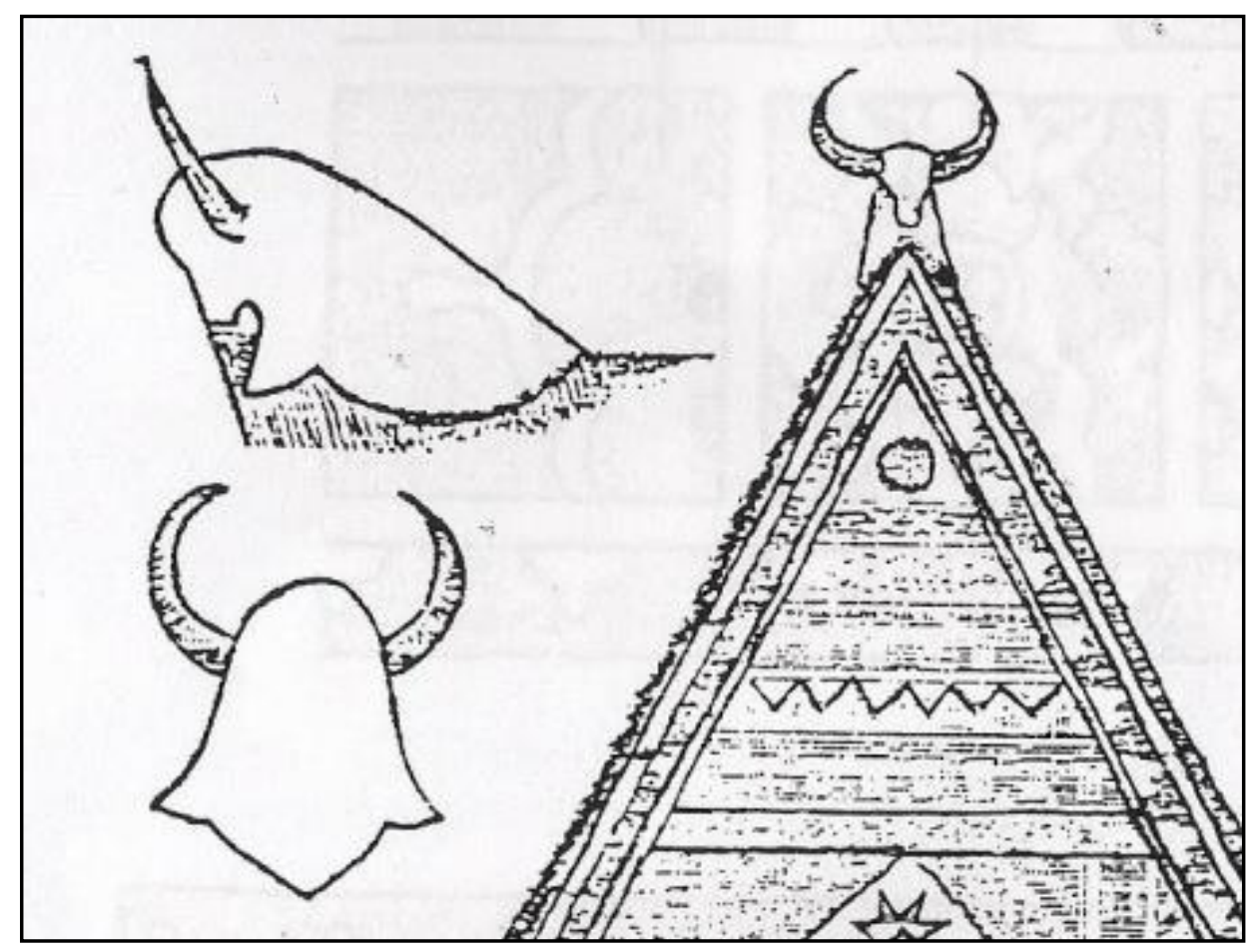

Figure 4. Buffalo Ornament 


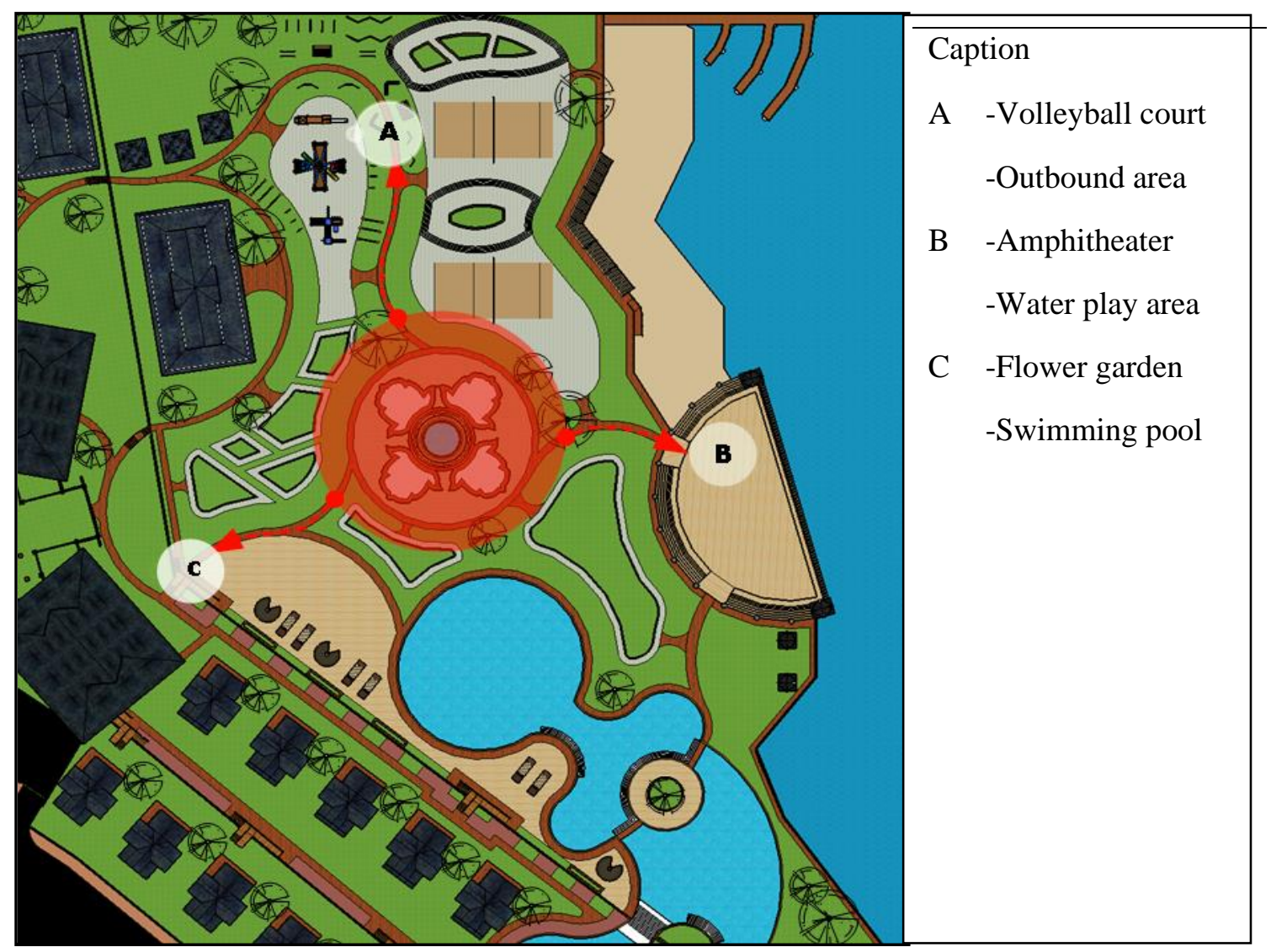

Figure 5. Application of Landscape Flexibility

This traditional house that was take was a "Gorga" house designated for the King. The application of this traditional house in the design of this hotel resort became the main concept in

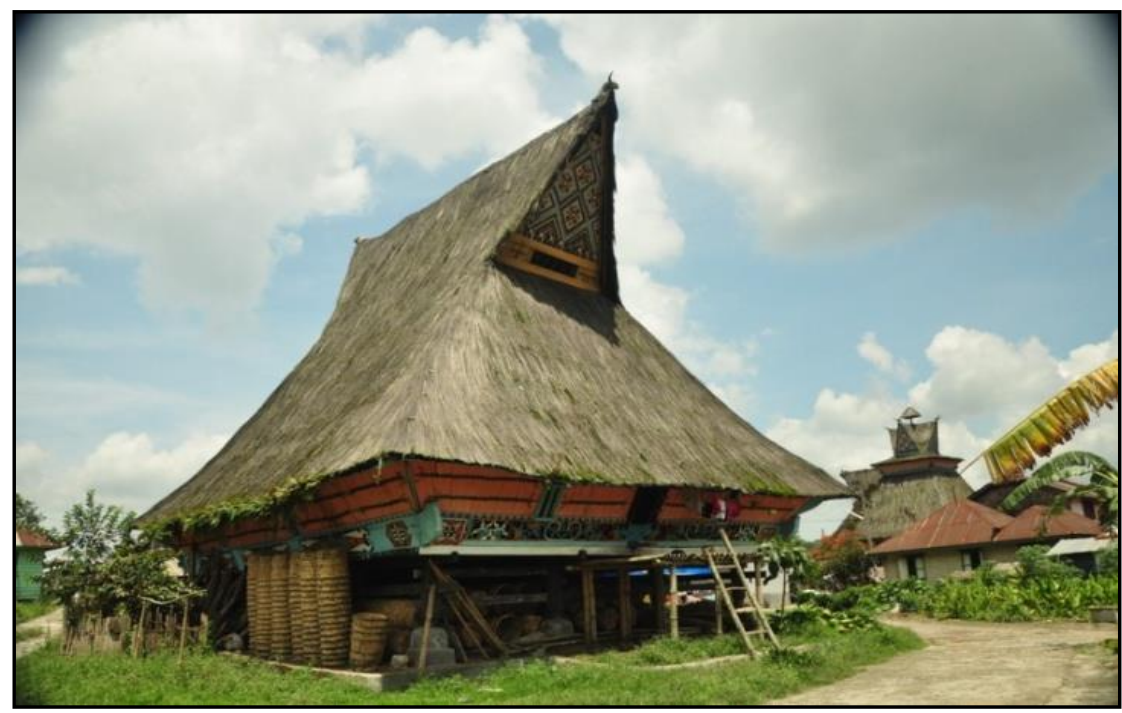


form and facade (Figure 6).

Figure 6. Traditional House Siwaluh jabu

The ornament taken is a lizard ornament that symbolizes the rejection of bad luck by the beliefs of the Karo people (Figure 7).

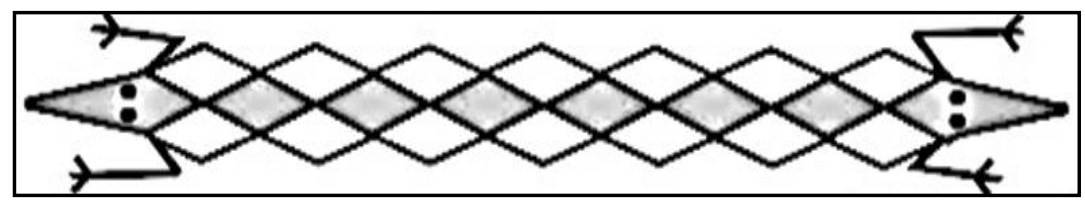

Figure 7. Lizard ornaments

The implementation of Karo Neo-Vernacular Architecture became the theme of this hotel resort because Karo tradition is still very thick at the location around the site of Tongging Village. The purpose of the build the hotel resort in Tongging Village is a solution to the development of tourism in Tongging Village itself where Tongging Village has so many natural potentials, good view, beautiful Lake Toba as well as the tourist attraction that should be supported by the fulfillment of lodging facilities that are able to attract local and foreign tourists to be able to stay,not only that this hotel resort presents a direct view towards the Lake Toba and views of the hill (Figure 8).

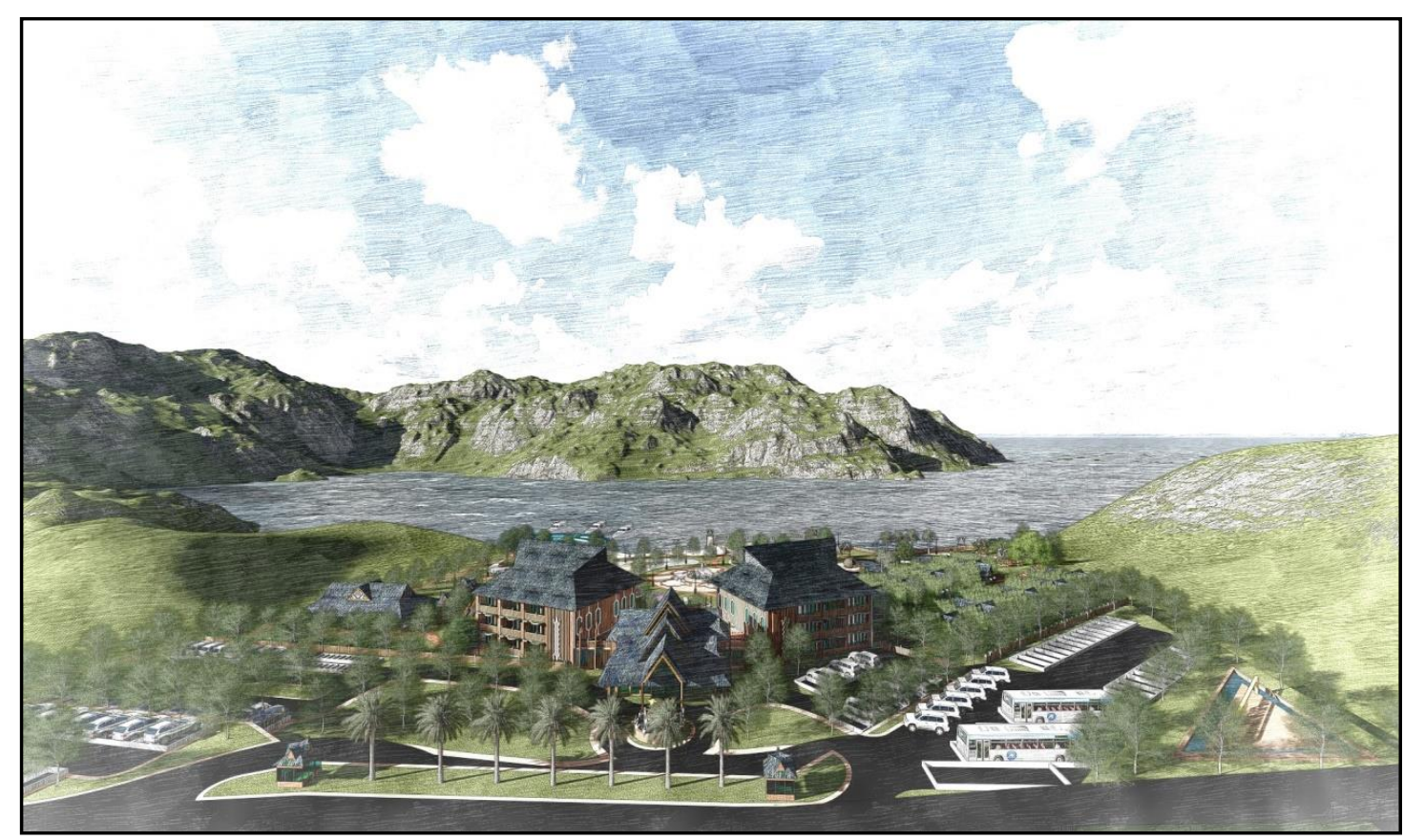

Figure 8. Main Building

With the concept of double-loaded concept, in every room is able to present a superb and also beautiful view. The facilities available at this hotel resort include hotel rooms with views 
towards Lake Toba and hills, fitness areas, spa, exhibition halls, galleries and many more. In addition to the indoor facilities provided at this hotel resort.

There are more outdoor facilities that will make tourists interesting to be able to visit this resort Hotel include the infinity pool, beach, flower garden, playground, tourist attraction, boat tour, and much more besides staying in a hotel room. Visitors can also use the cottage, where the view faces directly towards Lake Toba (Figure 9).

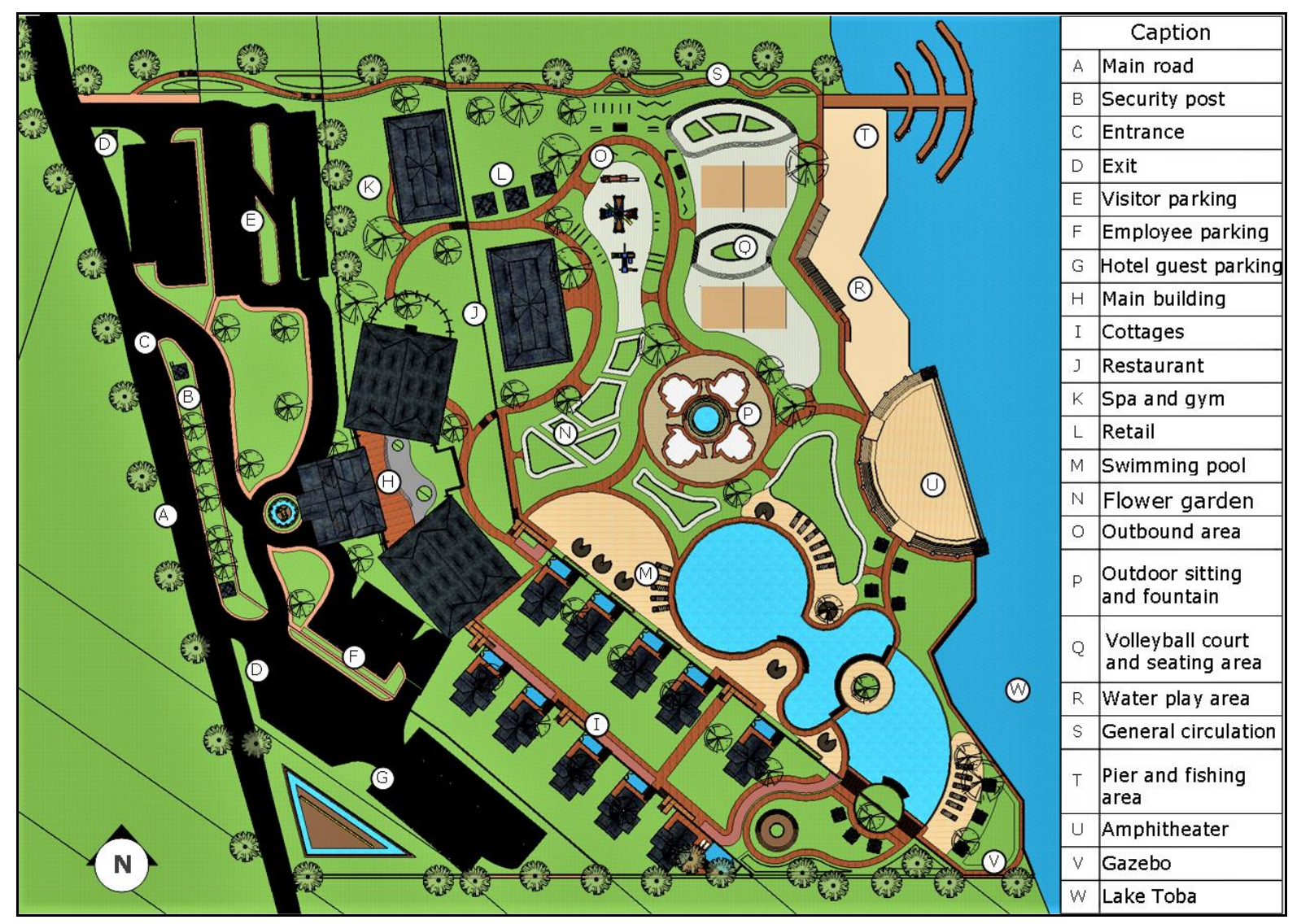

Figure 9. Site Plan

\section{Conclusion}

The conclusion is Tongging Village which is a tourist village in north Sumatera but rarely known by foreign tourists as well as local tourists. Increased accommodation and facilities become a background in improving the quality of attractions in the area. With this hotel resort, is expected to increase the interest of tourists to visit the Tongging village. The implementation of Karo's Neo-Vernacular architecture themes is a form of introduction and preservation of local wisdom of Karo that is still thick in Tongging Village. Outdoor and indoor facilities provided are able to increase the interest of local and foreign tourists as well as add the existing Tourism in the village of Tongging village and also in North Sumatera. 


\section{Acknowledgment}

These researchers have prepared this article and ware partly funded by the Department of Architecture Universitas Sumatera Utara as a contribution to the regional government in planning and design to maintain the local wisdom.

\section{REFERENCES}

[1] C. Y.Gee, "Resort Development and Management", New York: Watson-Guptil Publication, 1998.

[2] A. Putra, "Art Center Yogyakarta dengan Penekanan Desain Neo-Vernacular", Yogyakarta: Imaji. Vol.1,No.2., 2002.

[3] B. Roberto, "Mengenal Suku Karo", Jakarta: PT. Gramedia Pustaka Utama, PT. Kesaint Blanc Indah, 2006. 